\title{
Fiscal Feasibility Assessment Applied to Transport Infrastructure Projects
}

\author{
Joaquim José Guilherme de Aragão \\ Universidade de Brasília \\ Lílian dos Santos Fontes Pereira Bracarense \\ Universidade Federal do Tocantins \\ Yaeko Yamashita \\ Rayssa Brandão \\ Universidade de Brasília
}

\begin{abstract}
The demand for transport infrastructure investment is a latent issue for several countries, mainly for developing countries. However, investments in major logistics projects should be carefully evaluated, in order that their deployment induces development without endangering fiscal sustainability by excessive public indebtedness. Fiscal accounting practices used currently in the feasibility studies of transport infrastructures in Brazil are very limited, as they do not consider indirect and induced effects of the infrastructure investment in the fiscal evaluation. In addition, the corresponding influence area has not an established delimitation method. The aim of the present paper is to develop a model for calculating economic and fiscal impacts of transport infrastructure investment projects that includes the direct, indirect and induced effects within a reference area do be determined. First, different project assessment guides in Brazil and abroad are examined with a special focus on the assessment of economic and fiscal impacts of the projects. Based on the assessment experience and on the definition of the fiscal balance of an infrastructure project, the next step sets up a framework for the calculation of the impacts, using more simplified data.
\end{abstract}

\section{INTRODUCTION}

The technical, economic and environmental feasibility studies, more known as EVTEAs, are widely used in Brazil and worldwide as an assessment tool applied previous to project implementation, especially in large-scale projects (PGVs). These documents aim to "serve as background for project managers decision regarding the best way the execution of desired project actions should go" (Brasil, 2015); they also guide the assessment of subsequent operation performance with respect to the direct and indirect resulted effects of the investment on the social environment and financial results.

This analysis must be in agreement with governmental planning and, to that end, the fiscal conjecture inclusion is extremely important since it assures a better government debt management, which in its turn preserves fiscal sustainability and, thus, economic growth. 
According to Aragão et. al (2014), once fiscal expenses and revenues are contraposed, the projects that result in a positive fiscal liquid balance are listed more easily, and incentive rules can then be created, reducing excessive investments and bad resources allocation risks, especially in economic expansion phases. However, the current project evaluation practice in Brazil is limited, especially with respect to strategic investment planning, to cost control, and to project review procedures during and after its execution (World Bank, 2009 apud Aragão et al., 2014). The evaluation of fiscal impacts and of the impacts on overall fiscal sustainability are not on the agenda.

The present article aims to present a model of assessment of liquid fiscal impacts or infrastructure investment projects, which shall subsidize fiscal sustainability analysis. This document is divided by sections where the worldwide fiscal assessments practices are presented on the second section, followed by existing fiscal management methodologies and the comparison analysis of the documents; subsection 3 highlights the proposed model for fiscal sustainability assessment; conclusively, the main problems and recommendations are synthetized in Section 4. .

\section{THE WORLDWIDE PRAXIS OF FISCAL SUSTAINABILITY ASSESSMENT}

As discussed by Aragão et al. (2013), in general a sustainable process or policy suggests its maintenance for a long period of time without changes. Solvency is the main focus of the fiscal sustainability discussion, which is basically public debt management.

According to the International Monetary Fund (2002), the following principles and requirements must incorporate a wider fiscal sustainability definition, since every economic policy must be taken into account, not only the right public debts and deficits management;

- Solvency: the net present value (NPV) of the current and future primary deficit can't be bigger than the income's evolution NPV, free of any initial debt;

- Liquidity: independently from the general solvency condition, at each period the liquid assets and the available financing must be enough to meet or surpass its liabilities on the expiration date;

- Sustainability: the conditions above mentioned must be permanently satisfied, without the need of any important corrections to ensure revenues and expenses balance when great variability in financial costs are dealed on the market.

- Vulnerability: risk that liquidity and solvency conditions are violated and the borrower reaches crisis point.

It emanates from these definitions that the sustainability condition imposes, more than the mere compliance with solvency and liquidity rulings, the soft continuity of the policies, since the need for major corrections may provoke political disturbances which will hinder the adoption of the necessary but painful corrective measures. Taking under consideration the stochastic nature of the cash flows to be under control, the documentation includes also the 
vulnerability - which means "the risk of that the liquidity or solvency conditions are violated and the borrower enters a crisis" - into the components of the sustainability framework.

Therefore, the IMF's framework on FS is not only about the management of governmental debt and considers also the health of the financial sector as well the more general balance of payments and the stability of the exchange rate. In consequence, a very comprehensive assessment framework has been adopted by this institution, whereby the diagnostic of the fiscal health of each country is analyzed by means of an extensive plethora of data and indicators and also by case specific records on its historical evolution.

Despites being well used on international literature, the definition under consideration does not rely on the principle of maximum sustainable indebtedness level, but includes also the assessment of the interaction between public finance and the general economy essential for the mentioned balance (Balassone; Franco, 2002 apud Aragão et. al, 2014).

Along this lines, Balassone and Franco (2002) and Polito and Wickens (2005) proposed the subsequent initial conditions for fiscal sustainability:

- The evolution of debt quotient regarding the GDP must remain finite, converging eventually to its initial level;

- The NPV of the quocient of the primary deficit (or Superavit) to GDP must be equal to the negative (positive) value of the quocient of the current debt level in relation to GDP.

Even though the fiscal sustainability term is usually linked to the amount of public finances with some extension to the economic policy, Aragão et al. (2013) affirm the term may be used for finite projects if they directly contribute to fiscal sustainability as a whole, even in case they imply bigger government costs. Thus, the parameters to be assessed, according to Aragão et. al (2014 apud Morais et. al, 2014) are:

a) Solvency and Liquidity of projects, considering direct, indirect and induced effects.

b) The general fiscal balance shall not be severally damaged in the course of its implementation; particularly, the aggregated public indebtedness should meet stablished rules and limits for public indebtedness overall.

c) The internal fiscal management of each project should ensure robust results regarding different vulnerabilities, mainly fluctuations on interest and exchange rates, and growth.

Aragão et al. (2013) highlight the calculation procedures to determine fiscal revenues associated to the project, which are quite complex as they involve the economic growth associated to the project. This issue is here addressed.

\subsection{Existing fiscal management methodologies and comparative analysis of guideline documents}

In order to review the international reference for fiscal feasibility studies of infrastructure 
projects, a qualitative research was made. The selected documents were the following:

- Feasibility Studies Manual of the United States - Principles and Requirements for Federal Investments in Water Resources (USA, 2013), here referred as PRG-USA;

- Costs and benefits analysis manual of the investment projects (COMISSÃO EUROPEIA, 2003), here referred as MCB-EU;

- Handbook on economic analysis of investment operations (World Bank, 1998), here referred as HEA-WB; and

- Presentation Manual of Large-Scale Projects Feasibility Studies (BRASIL, 2009), here referred as MEV-BR.

In Brazil, fiscal management is demanded by Supplementary Law $\mathrm{n}^{\circ}$ 101/00 (Fiscal Responsibility Law - LRF), and it is assessed through the Fiscal Management Report instrument. This document has the purpose of ensuring greater transparency of the country's debt management, comprising the control, the monitoring and publishing of the percent debt level in relation to the current net revenue. The non-release of the report constitutes an administrative infraction against public finance laws (Brasil, 2015).

Notwithstanding, MEV-BR does not include a mandatory fiscal impact analysis. At most, stress tests, risk analyses and monitoring of project implementation and of its posterior operation are foreseen.

In the United States, "since the 1930's a tradition of evaluating net fiscal results can be traced mostly to justify to the public urban renovations, zoning and other great impact projects" (Burchell et al., 1985 apud Aragão et al., 2014). Initially, North-American counties have compared the mean costs per beneficiary and the marginal costs in similar projects (Kotval; Mullin, 2007; CMAP, 2014apud Aragão et al., 2014 ).

In order to evaluate specific projects, however, many fiscal assessment manuals of urban projects have been disseminating worldwide techniques which include the direct effects generated by the project implementation. With respect to other effects, such as indirect and induced impacts and as well to economy dynamics, the respective assessment procedures have to be obtained in the wider literature. For these effects, following definitions are delivered (Weisbrod, 1997; Keane, 1996; Kotval; Mullin, 2006 apud Aragão et al., 2014):

- Direct effects: comprise investment and expenditure decisions, public and private costs, as well change in local advantages that may attract new investments;

- Indirect effects: are measured by the billing from supplying industries to the projects;

- Induced effects: the can be derived from the purchasing power of the contracted workforce that will imply in consumption and in rising demand for the respective chains.

- Dynamic economic effects: they result from the changes in local population and businesses level; the effects are also denominated catalytic impacts. 
On its turn, the fiscal analysis proposed by the PRG-USA Handbook does not foresee the assessment of concrete fiscal impacts or resulting effects of the project within the project area. Similarly to the Brazilian handbook, a simple risk assessment and a stress test shall follow the conventional feasibility studies for each project alternative

For each study, the reliability and the limits of the available information has to be assessed. This include the identification, the probability and consequences of risks, as well the uncertainties associated with data, projections and alternatives evaluations. The possibility of reduction of risks and uncertainties need to be considered in the studies of the alternatives and of the final project.

The method used in World Bank, which gives an international standard for feasibility studies, is the only one of the here mentioned documents that foresees fiscal impact assessment. This assessment shall comprise:

- Fiscal policies that are necessary for macroeconomic stability;

- Project costs and their recovery by the beneficiaries;

- Impacts on public expenses and revenues due to the project;

- Net effects for local and central governments;

- Accounting of the non-retrievable portion of the projects

\section{TOOLS AND PARAMETERS FOR THE ASSESSMENT OF THE FISCAL SUSTAINABILITY}

The proposed model for fiscal sustainability assessment comprises two major phases, as presented on Figure 1.

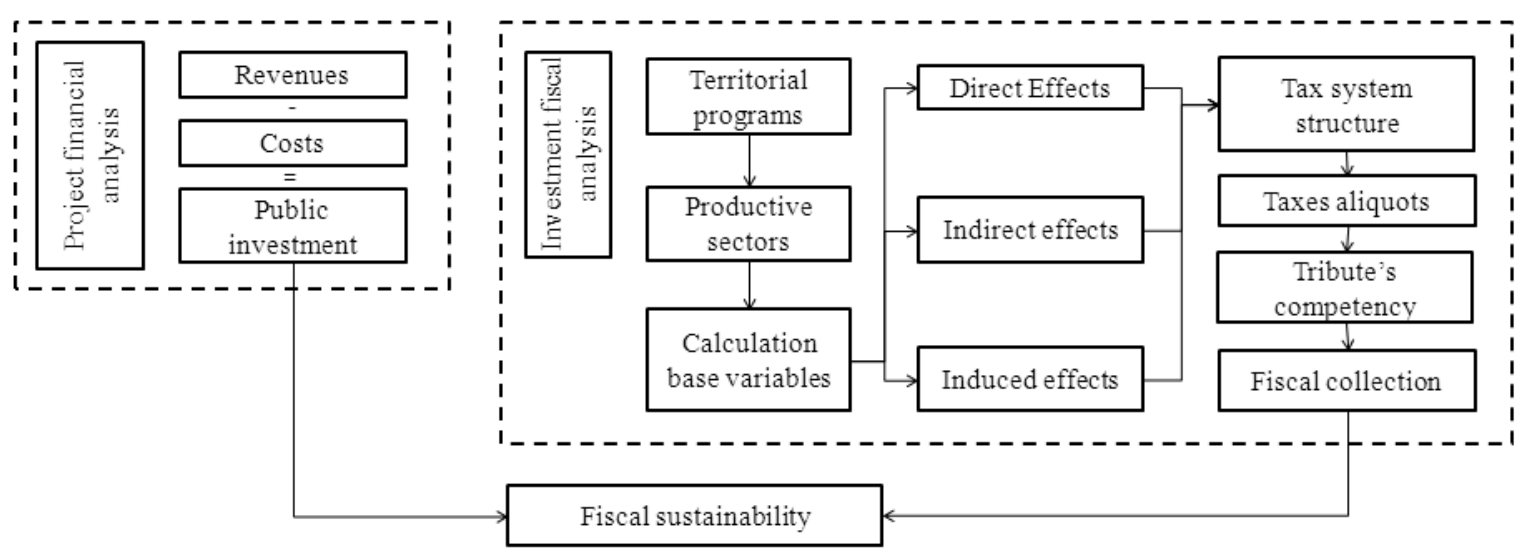

Figure 1 - Modeling complex for economic and fiscal impacts assessment of large-scale projects

The first phase corresponds to the financial analysis of the transportation infrastructure project, whose method is very well known by professionals involved in feasibility studies. 
From the listing of the costs of implementation, operation and maintenance and of the generated revenues it is possible to evaluate which public resources would be necessary to enable the project in case direct revenues are not enough to cover the costs.

The fiscal analysis of the indirect and induced impacts, the second major phase, may subdivided into the following sub-phases:

- Identification of productive sectors involved in the production of the referred infrastructure project;

- Study of the supply chains of the productive sectors, aiming to identify activities related to direct, indirect and induced effects;

- Analysis of the tax system structure for each government level involved in the project, including the identification of the aliquots $(\alpha)$ and the calculation base (vm) of different taxes (n);

- Calculation of the base variables (income, production output, etc) for every product segment, comprising their direct (d), indirect (i) and induced (f) levels.

- Subsequently a conservative estimate of the fiscal revenue (RF) can be made and be compared to the investment amount (see Equation 1)

$$
\mathrm{RF}=\sum\left(\alpha_{\mathrm{n}, \mathrm{d}} \times \mathrm{v}_{\mathrm{m}, \mathrm{d}}\right)+\sum\left(\alpha_{\mathrm{n}, \mathrm{i}} \times \mathrm{v}_{\mathrm{m}, \mathrm{i}}\right)+\sum\left(\alpha_{\mathrm{n}, \mathrm{f}} \times \mathrm{v}_{\mathrm{m}, \mathrm{f}}\right)
$$

Subsequently, the fiscal impacts will be obtained from the multiplier effects described in section 2.1, which comprise direct, indirect and induced effects. Dynamic interferences will be ignored since they will not be under the direct control of the project management (Aragão, 2014). The result of the calculation is a conservative estimation since the inclusion of direct and induced effects could reach too many levels, making the measuring impracticable. For aims of simplification, only one or two analysis levels (direct and indirect effects) are adopted depending on data precision. Some examples of impacts to be identified are mentioned in HEA-WB: project costs recovery by their beneficiaries; changes in public expenses included foreseen for the project; net effect for the central and local government; the distribution of benefits and costs among stakeholders, among others.

\section{CONCLUSIONS}

As mentioned on Section 2.1, fiscal impacts are not taken in consideration on feasibility studies realized in Brazil. Therefore, the consideration of possible direct, indirect and induced impacts should be assessed. For this aim, methodological guidelines and tools that should be adopted.

As shown above, the procedures foreseen by the MEV-BR handbook specify the stress tests and risk analysis and monitoring. However, it does not assess general indirect costs and benefits on the respective sensitive evaluation, harming the whole project assessment due to 
the imprecision in calculating costs and revenues that will be relevant for the cash flow.

A faulty definition of the study area may also lead to errors in the calculation of the impacts, since they may ignore, sub estimate or overestimate impacts produced in remote locations. On the top of this social and environmental aspects like climate changes and future soil use and other mentioned in the PRG-USA Handbook are not assessed.

It is recommendable that following impacts referenced in HEA-WB should be taken into consideration: the value of the project costs to be recovered by beneficiaries (stakeholders) and the respective collection procedure; impacts on public expenses and revenues due to the project; net results for the local and central government; accountancy of the nonrecoverable portion of the investment; finally, the fiscal policies needed for ensuring macroeconomic balance. These results should also be separated accordingly to the impacts categories proposed by Weisbrod (1997), Keane (1996) and Kotval and Mullin (2006).

With respect to the calculation framework for fiscal impacts and for the level of fiscal sustainability the model presented in Section 3 relies on the tax structure applicable for the project region, which will be used in the calculation of direct, indirect and induced effects. The financial analysis must also take in account the temporal dimension, the sustainability requirements and the forecasts of the annual fiscal revenues during the project life.

\section{ACKNOLEDGEMENTS}

The authors thank CNPq and FAPDF for the financial support.

\section{REFERENCES}

ARAGÃO, J. J. G.; YAMASHITA, Y.; ORRICO FILHO, R. (2013) The Evaluation of the Fiscal Sustainability of Transportation Infrastructure Investment within Territorial Programs. 13th WCTR, July 15-18, 2013 - Rio de Janeiro, Brazil

ARAGÃO, J. J. G., YAMASHITA, Y., ORRICO FILHO, R. D. (2014). Projetos de grande vulto: sua auditagem e promoção. - Universidade de Brasília - Laboratório de Infraestruturas (INFRALAB). Brasília.

BALASSONE F, D Franco (2002): Assessing Fiscal Sustainability: A Review of Methods with a View to EMU. In: Banca d'Italia (2000): Fiscal Sustainability. Essays presented at the Bank of Italy workshop held in Perugia, 20-22 January 2000.

BRASIL. Lei complementar $n^{\circ} 101$, de 4 de maio de 2000. Estabelece normas de finanças públicas voltadas para a responsabilidade na gestão fiscal e dá outras providências. Diário Oficial [da] Republica Federativa do Brasil. Brasília, 4 maio 2000.

BRASIL. Ministério do Planejamento, Orçamento e Gestão. Comissão de Monitoramento e Avaliação do Plano Plurianual. (2009) Câmara Técnica de Projetos de Grande Vulto. Manual de apresentação de estudos de viabilidade de projetos de grande vulto. Versão 2.0. Brasília: MP, 2009. 52p. 
BRASIL. Tribunal de Contas da União. (2015) Acórdão N 1787/2015. Brasília: TCU, 2015. $10 \mathrm{p}$.

COMISSÃO EUROPEIA(2003) Manual de análise de custos e benefícios dos projetos de investimento. Bruxelas: CE 155p.

DALBEM, M. BRANDÃO, L.; MACEDO-SOARES, T. D. (2010) Avaliação econômica de projetos de transporte: melhores práticas e recomendações para o Brasil. Revista de Administração Pública, Rio de Janeiro, v. 44, n. 1, p. 87-117, jan./fev. 2010.

INTERNATIONAL MONETARY FUND (2002): Assessing Sustainability, International Monetary Fund, Washington, DC.

POLITO V, M WICKENS (2005): Measuring Fiscal Sustainability. Centre for Dynamic Macroeconomic Analysis Conference Papers 2005. Castlecliffe: University Of St Andrews.

Soares, F. A. R., Moreira, T. B. S., J. O. (2011) Credibilidade e Sustentabilidade da Política Fiscal no Brasil: uma Avaliação Empírica. In: IV Prêmio SOF de Monografias.

UNITED STATES OF AMERICA. Executive Office of the President. Office of Management and Budget; Council on Environmental Quality (2013) Principles and Requirements for Federal Investments in Water Resources. Washington: EOP, 16p. Interagency Guidelines. In: . Principles and Requirements for Federal Investments in Water Resources. Washington: EOP, mar. 2013. Ch. 3.

World Bank (1998) Handbook on economic analysis of investment operations. WBH. 209p. TRN-8. Transport Notes. Fiscal impacts: the fiscal impacts of transport investments. Washington: WB, jan. 2005. 4p. 